\title{
The Women and Peace Hypothesis in Peacebuilding Settings: Attitudes of Women in the Wake of the Rwandan Genocide
}

$\mathrm{T}$

he "women and peace" hypothesis suggests that at the microlevel women hold more pacific or compromising attitudes than men (Tessler and Warriner 1997; Tessler, Nachtwey, and Grant 1999). ${ }^{1}$ Even though this hypothesis concerns individuals, empirical research has hitherto focused on attitudes toward war at the macro, interstate level in the West and Middle East. In Western countries, questions posed have concerned, for example, attitudes toward using military means or initiating a war in a foreign country (Conover and Sapiro 1993; Eichenberg 2003). In the Middle East, questions have focused on whether women are more pacific than men in their attitudes toward the Arab-Israeli conflict (Tessler and Warriner 1997; Maoz 2009).

But what happens in the wake of war? For the first time, this study brings the women and peace hypothesis to the postconflict, peacebuilding setting. It argues that due to the particular circumstances of a country after civil war, not only must the questions surrounding the women and peace hypothesis shift from focusing on attitudes toward war to focusing on attitudes toward peace, but war-related trauma must be integral to the debate. Knowledge of women's and men's psychological health and attitudes toward peacebuilding in postconflict settings may provide valuable information for understanding the challenges of peacebuilding and ultimately for improving the prospects for peace. By studying the relation between war-related psychological ill health and attitudes about trust, coexistence,

I wish to thank the Norwegian Foreign Ministry for funding the early phases of this study. My sincere gratitude goes to Mats Hammarström, Department of Peace and Conflict Research, Uppsala University, for excellent comments when I was preparing this essay. I am grateful to the National Centre for Peace and Conflict Studies, University of Otago, for supporting me in finishing this article. For laying the groundwork for this report, I am indebted to my colleagues at the International Rescue Committee (IRC), Kigali, for invaluable assistance with the survey in Rwanda, and to the Swedish International Development Cooperation Agency, Sida, which funded this survey. Finally, I thank the Rwandan women and men who participated in this study for sharing their views on the peacebuilding process.

${ }^{1}$ As in previous research on the women and peace hypothesis, this study focuses solely on attitudes toward peace, not similarities or differences in behavior (i.e., work for peace). This would, however, be an important avenue for future research. I am grateful to one of the anonymous reviewers for pointing out this important distinction.

[Signs: Journal of Women in Culture and Society 2014, vol. 40, no. 1]

(c) 2014 by The University of Chicago. All rights reserved. 0097-9740/2014/4001-0014\$10.00 
and the gacaca (the Rwandan peacebuilding process) among women and men twelve years after the genocide, this study extends the women and peace hypothesis to the peacebuilding phase. $^{2}$

The genocide in Rwanda has been described as one of the most extensive of our time (Prunier 1995; Melvern 2000). Over the course of one hundred days, from April to July 1994, approximately eight hundred thousand people were murdered. Men, women, and children were killed, most of them members of the Tutsi ethnic minority group, but ethnic Hutu who opposed the Hutu extremist regime were also executed. It has been called an intimate genocide (Staub and Pearlman 2001) in which neighbors murdered neighbors and family members murdered family members. The genocide affected everyone and had severe consequences for psychological health.

In 1999 and 2002, depression and posttraumatic stress disorder (PTSD) were assessed in two separate studies in Rwanda, revealing high levels of both (Bolton and Ndogoni 2000; Pham, Weinstein, and Longman 2004). A recent article demonstrated that by 2006 these levels remained staggeringly high (Brounéus 2010).

Considering these high levels of depression and PTSD in the Rwandan population, the present study set out to investigate the relationship between gender, psychological ill health, and attitudes toward trust, coexistence, and the gacaca. As mentioned, the women and peace hypothesis

\footnotetext{
${ }^{2}$ The gacaca has been - to my knowledge - the largest state-driven truth and reconciliation process in the world thus far. Launched nationwide in 2005, over twelve thousand gacaca courts have taken place, with mandatory participation for the population. Lay judges were elected locally, nine for each gacaca court. The crimes of the genocide were categorized, and punishment was administered by the gacaca judges after hearing testimony from victims, villagers, and the perpetrators themselves. The gacaca process has received both praise and criticism. Building a truth and reconciliation process on a traditional justice management system only a few years after genocide is an impressive undertaking, and stories of successful reconciliation between former enemies have been heard. Nevertheless, severe problems do exist. Equal justice has not been provided to all; for example, acts committed by the present government's forces during and in the aftermath of the genocide are not dealt with in the gacaca, leading to the impression that a "victor's justice" is being made, nor has the safety of victims been secured. Witnesses have been threatened and in some instances killed; women, especially widows, may have been particularly vulnerable to such acts of intimidation (Human Rights Watch 2004; Brounéus 2008). Further, genocide-related rapes were dealt with in Rwanda's conventional court system up until May 2008, at which point they were transferred to the gacaca. For many women, this led to increased fear. Even though closed hearings for rape have been possible, the public and locally based nature of the gacaca has led to insecurity as to the level of confidentiality (Human Rights Watch 2011). Initially planned for completion by the end of 2007, the gacaca was extended; however, on May 4, 2012, the gacaca was officially closed. For further reading on the gacaca, see, e.g., Sarkin (2001), Uvin (2003), Bolocan (2004), Clark (2007), and Ingelaere (2008).
} 
has been tested in the West and the Middle East regarding attitudes toward military means and interstate war but has not previously been applied to an African setting after civil war. Considering that over the last two decades nearly all conflicts in the world have been civil wars, most of which have taken place in Africa (Harbom and Wallensteen 2010), extending the women and peace hypothesis to an African peacebuilding context seems warranted.

For these purposes, I have analyzed data from a multistage, stratified cluster random survey of 1,200 Rwandans conducted in four provinces of Rwanda in March 2006. The results demonstrate that women were significantly more negative than men in three attitudes of relevance for peacebuilding: trust, coexistence, and the gacaca. This finding is in stark contrast to the mixed results of the women and peace hypothesis at the interstate level, which have found either no difference between women and men or that women hold slightly more dovish or compromising attitudes than men (Conover and Sapiro 1993; Tessler and Warriner 1997). Further, women in this study reported significantly higher levels of depression and PTSD than men, a finding in line with previous research. Finally, women in this study also reported having experienced more traumatic events than men. This finding is in contrast to previous research, much of which was based on nonwar populations (Gavrandidou and Rosner 2003; Solomon, Gelkopf, and Bleich 2005). Women in this study were, for example, subjected to more sexual and nonlethal violence and to more traumatic events during the genocide than men. Taken together, the findings of this study propose that as more women are left to survive the atrocities of war, they may carry a heavier burden of war-related memories in their bodies and minds. This may explain women's more negative attitudes toward issues related to peace - and why the women and peace hypothesis does not seem to hold in the wake of war.

This article proceeds as follows: First, I present an overview of previous literature on the women and peace hypothesis. Next, a theoretical framework for bringing the women and peace hypothesis to peacebuilding is developed, drawing on the literature on war-related trauma and gender differences in depression and PTSD. Thereafter, I formulate three hypotheses based on this previous research. The results of the study are then presented, followed by a discussion. The article concludes with ideas for future research and with the policy implications of the results.

\section{The women and peace hypothesis and war waging}

The debate over the women and peace hypothesis can be seen as being held at two equally influential yet quite separate levels, one macro and one 
micro. At the macrolevel, the debate essentially refers to how gender equity and equality affect the conditions of a state and how these in turn affect gender equality. For example, gender equality within a country has been found to have a pacifying effect on human rights abuse (Melander 2005b), intrastate armed conflict (Caprioli 2005; Melander 2005a), and international conflict (Caprioli 2000; Caprioli and Boyer 2001). Other studies at the macrolevel have demonstrated that societies with high levels of domestic violence are involved to a greater extent in violent conflict and war (Erchak and Rosenfeld 1994; Ember and Ember 1997; Cockburn 2001). Finally, a recent study found a strong, significant relationship between the physical security of women and the peacefulness of the state (Hudson et al. 2008/9).

At the microlevel, the level on which the present study focuses, the women and peace hypothesis proposes that women tend to hold more peaceful or compromising attitudes than men with regard to international relations, for example, concerning the support of military force or the initiation of war. The academic debate on why such a difference would exist includes a wide range of theoretical arguments. At one end of the spectrum, scholars have advocated the female experience of motherhood-emphasizing traditionally female characteristics such as empathy and caring-as the basis for such a difference. At the other end, the economic marginalization of women has been presented as a driving cause, the argument being that women would not want scarce economic means to be spent on military costs. ${ }^{3}$ More recently, Erik Melander has suggested that the theoretical reasons women would be more positive toward peace can be categorized into two frameworks: the "essentialist argument" and the "constructivist argument” (2005a, 696). The essentialists hold that these attitudinal differences around peace and war can be attributed to inherent biological differences between women and men-that women by nature are more opposed to violence. The constructivists, on the other hand, argue that attitudes toward war and peace are explained by the socialization of gender roles (2005a). Important feminist scholars in international relations have indeed amply critiqued the women and peace hypothesis on theoretical grounds, stating that the question has been oversimplified and that myths and stereotypical concepts of what is female and male trap and distort our understanding of war and peace. ${ }^{4}$

\footnotetext{
${ }^{3}$ For references and an excellent review of this literature, including criticisms against it, see Tessler, Nachtwey, and Grant (1999).

${ }^{4}$ See Elshtain (1987), Tickner (1992), Sylvester (1994), Ruddick (1998), and Confortini (2012).
} 
However, while the theoretical discussion of the women and peace hypothesis at the microlevel is rich, the empirical work is more limited and yields mixed results. In Western countries such as the United States, questions have been either hypothetical, regarding, for example, attitudes toward general questions of using military means, or concrete, concerning attitudes toward the initiation of a war in a specific foreign country (e.g., the First Gulf War). Findings include that women are more dovish in their attitudes than men, albeit with the reservation that the differences are "by no means large enough to ... warrant making the kinds of sweeping statements differentiating women and men that have long been part of [the popular] stereotype" (Conover and Sapiro 1993, 1095), and that women are less supportive of the use of military force than men (Wilcox, Hewitt, and Allsop 1996; Eichenberg 2003). In the Middle East, studies have investigated the relationship between the women and peace hypothesis and the ongoing Arab-Israeli conflict from several different angles. Using public opinion data from nine Middle Eastern countries, Mark Tessler and his colleagues found no significant relationship between gender and attitudes toward the Arab-Israeli conflict (Tessler, Nachtwey, and Grant 1999). In an experimental study of the women and peace hypothesis and the effect of the opponent negotiators' gender on proposals for compromise in the protracted Israeli-Palestinian conflict, Ifat Maoz (2009) did find a gendered evaluation effect. For example, a compromise offered by a female negotiating opponent was valued more favorably than when offered by a male negotiator. Finally, in one of the only studies using questions about interstate peace instead of war, while no gender differences were found regarding willingness to participate in peace encounters, women were found to be more positively consistent in their attitudes toward peace than men (Yablon 2009). In sum, previous empirical research on the women and peace hypothesis at the microlevel has concerned attitudes toward war in the West and Middle East; at the macrolevel and interstate level, it has been studied in hypothetical terms, before armed conflict, or during ongoing conflict, yielding mixed results.

\section{The women and peace hypothesis and peacebuilding}

The present study brings the women and peace hypothesis microlevel debate to the peacebuilding setting of Rwanda. In doing so, two refinements of the women and peace hypothesis are made. First, given the particular circumstances of a post-civil war setting, asking questions about the use of military means or initiation of war seems irrelevant: it is likely that few among the general population in the aftermath of war support the con- 
tinuation of armed violence, and answers to such questions would not be particularly instructive for the peacebuilding phase. On the other hand, knowledge of women's and men's attitudes toward peacebuilding in postconflict settings would provide valuable information for understanding the challenges of peacebuilding faced by women and men and ultimately for improving the prospects for peace. Hence, three sets of questions relevant to peacebuilding were developed: how the interviewees felt regarding trust, how they felt concerning coexistence, and how they believed the gacaca contributed to peaceful coexistence and well-being.

Second, in order to build theoretical expectations of what may be found when bringing the women and peace hypothesis to a peacebuilding context, this study turned to research on war-related trauma and psychological health. War entails grave psychological suffering with effects on people's lives long after the war has ended (Okasha 2007); a gendered analysis of postwar psychological ill health and peace-related attitudes may shed important light on peacebuilding. ${ }^{5}$ Existing psychological research has consistently demonstrated that war leads to significant psychological suffering and disorder (Mollica et al. 2004; Okasha 2007; Srinivasa Murthy 2007). The reported prevalence of psychological ill health in war-affected populations includes PTSD levels of 34 percent in Timor Leste (Modvig et al. 2000) and depression levels of 55 percent among Cambodian refugees in Thailand (Mollica et al. 1993). Further, epidemiological research suggests a strong gender effect in PTSD. ${ }^{6}$ This effect pertains to three main areas. The first concerns the risk of being exposed to a traumatic event: men report higher trauma exposure than women. The second concerns the type of traumatic events: women are exposed more to sexual abuse and rape, men more to physical attacks and serious accidents. The third concerns the prevalence of PTSD: women are more than twice as likely to develop PTSD as a result of trauma as compared to men (Gavrandidou and Rosner 2003; Solomon, Gelkopf, and Bleich 2005). The same gender difference is found in depression, with women at twice the risk as men (Weissman et al. 1996; Haskell et al. 2010; Van de Velde, Bracke, and Levecque 2010).

\footnotetext{
${ }^{5}$ Four studies constitute the existing evidence about the effects of psychological ill health on peacebuilding, all of which demonstrate that PTSD and depression seem to lead to more negative attitudes toward peace (Pham, Weinstein, and Longman 2004; Bayer, Klasen, and Adam 2007; Vinck et al. 2007; Stein et al. 2008); however, none of these previous studies has considered gender differences.

${ }^{6}$ See Breslau et al. (1998), Brewin, Andrews, and Valentine (2000), Stein, Walker, and Forde (2000), and Ventevogel et al. (2007).
} 
The effect of gender in the development and prevalence of PTSD is complex. It has been suggested that the differences between men and women may be explained by methodological issues, social gender roles, coping strategies, or report bias (Gavrandidou and Rosner 2003; Solomon, Gelkopf, and Bleich 2005). It has also been suggested that these phenomena also play a role in the higher levels of depression reported by women (Ventevogel et al. 2007). Importantly, the hypothesis that men underreport and women overreport psychological suffering due to cultural and traditional gender norms is prevalent in the literature (Hunt and Annandale 1999). However, Sally Macintyre and her colleagues found no evidence that women report more, or more trivial, mental health conditions than men (Macintyre, Ford, and Hunt 1999).

Let us now turn to the particular situation of war-related PTSD and depression. War strikes men and women differently (Tickner 1992; Jones 2000; MacKinnon 2005). More men are killed in war, while women are more often subjected to nonlethal forms of violence such as sexual violence or being forced to see family members being killed (Human Security Centre 2005). This implies that as men are killed to a greater extent, the women who survive may experience higher levels of severe psychologicaland physical yet nonlethal - trauma. Further, recent research suggests that symptoms of PTSD and depression may vary with the type of trauma exposure (Pham, Weinstein, and Longman 2004; Vinck et al. 2007). The type of trauma women are exposed to in war, such as sexual violence or witnessing the death of family members, may be associated with a higher risk of psychological ill health, which in turn may explain why women report higher levels of psychological ill health after war. Moreover, experiences of sexual violence, for example, lead to deep difficulties after the war; sexual violence is often associated with deep feelings of shame, guilt, and stigma (Herman 1997; MacKinnon 2005; Brounéus 2008). Recent literature suggests that the long-lasting health problems of war affect women disproportionately due to the societal changes during and after war, which adversely affect women's health (by ignorance or neglect), and due to the social stigma attached to war crimes such as rape, which affect the lives of women long after the war is over (Arcel and Kastrup 2004; Okasha 2007). Indeed, sexual violence in war, it has been suggested, leads to particular challenges for many women in transitional justice processes after war (McKay 2000). Furthermore, as more men are killed in war, more women are widowed. Social support has been found to have an important protective effect against PTSD, particularly among women (Ahern et al. 2004). Since many women lose their family networks as a result of war, this may be an aggravating factor for their psychological health. 


\section{Research hypotheses}

I formulate three interrelated research hypotheses linking war-related trauma as well as depression and PTSD to attitudes with relevance for peacebuilding. As discussed, women and men are subjected to different types of atrocity in war, with more men being killed and more women being victims of sexual and nonlethal violence (Human Security Centre 2005). This would suggest that in postwar settings, as opposed to nonwar settings, women will report higher levels of trauma exposure than men. Further, research consistently demonstrates that women report higher levels of depression and PTSD than men (Gavrandidou and Rosner 2003; Solomon, Gelkopf, and Bleich 2005). This "overreporting" of psychological ill health in women has previously been interpreted as an expression of cultural gender norms regarding the way women and men report suffering - that women overreport and men underreport suffering (Hunt and Annandale 1999). But do women wail? After war, women are left to live with high levels of trauma imprinted on their bodies and minds. The socalled dose-response relationship between the amount of traumatic events and the prevalence of mental disorder is well documented in the literature (Srinivasa Murthy 2007). The first and second hypotheses capture these relationships, suggesting that after war, women report higher levels of warrelated trauma and higher levels of psychological ill health than men:

Hypothesis 1. Women will report higher levels of war-related trauma events than men.

Hypothesis 2. Women will report higher levels of depression and PTSD than men.

Finally, if women are subjected to higher levels of war-related trauma and report higher levels of postwar depression and PTSD, women may also find peacebuilding issues such as integration, coexistence, and the peacebuilding process in general more challenging than men. After civil war, living side by side must continue, just as before the war. The difficulty of seeing one's perpetrator on the street or living as one's neighbor should not be underestimated. Hence, building on hypotheses 1 and 2, the third hypothesis suggests that women will demonstrate more negative attitudes than men toward issues of relevance for peacebuilding (here defined as trust, coexistence, and the gacaca), thereby contextualizing the women and peace hypothesis for the peacebuilding phase:

Hypothesis 3. Women will demonstrate more negative attitudes toward trust, coexistence, and the gacaca process than men. 


\section{Methods}

Detailed information about the design, questionnaire development, instruments, and algorithms used for assessing symptoms of PTSD and depression can be found in a previous publication (Brounéus 2010) or upon request from the author. Accordingly, only a summary of these considerations will be given here.

\section{Ethical considerations, ethical review, and local research partner}

Conducting a study on experiences of trauma, truth, and reconciliation in a postconflict setting requires fundamental ethical considerations and careful methodological design. Not only does the researcher need to think of what is being researched, there is also a need to consider how it is done and the possible consequences the research may bring. Designing ethically sound field research involves reflecting from the beginning on the ethical dimensions of issues such as the selection of cases and subgroups, the sampling of interviewees, the timing and place for conducting the interviews, and the seemingly tiny details of how to formulate the survey questions. It is important to make an ethically informed risk assessment concerning how to access interviewees in the safest possible way and how to ensure the participants' security and confidentiality during and after the interview. In this lies, in addition to the issue of merely accessing information, the question of determining what information should be gathered; it is important to decide carefully what needs to be asked to minimize the risk of doing harm. Speaking of traumatic events is difficult and may in the worst cases lead to retraumatization. By treading carefully and including only the most essential questions for understanding the research question at hand, it is possible to minimize such risks (Ackerly, Stern, and True 2006; Ackerly and True 2010; Brounéus 2011). These issues were reflected upon and discussed at length before, during, and after the project was carried out.

My department ethically reviewed and authorized this research project, and detailed discussions were held continuously during the extent of the project to ensure that the highest standards of research methodology were met (Ford et al. 2009). In Rwanda, the research project was ethically and methodologically reviewed and approved by the National Unity and Reconciliation Commission, the National Institute for Statistics at the Ministry of Finance, and Ibuka (the National Association of Genocide Survivors), the three authorities from which permission was required for a study of this scope.

The International Rescue Committee (IRC) in Kigali was contracted to conduct the survey. A team of twenty-one Kinyarwanda-speaking research 
assistants and three team leaders were selected on the basis of having exemplary interviewing skills and extensive experience in working with surveys for the IRC. Half of the research assistants were women; all three team leaders were men. Particular concern was made to select research assistants of both Hutu and Tutsi descent. A two-day training workshop was held, in which the aim and contents of the survey, as well as the importance of listening, confidentiality, and anonymity, were described and discussed in depth.

\section{Survey sites, sampling procedure, and collecting the data}

During twelve days in late March and early April 2006, the team of twentyone trained research assistants led by three team leaders carried out 1,200 interviews with a structured survey questionnaire in four provinces in Rwanda. Since January 1, 2006, Rwanda has been divided into five provinces, which in turn are divided into thirty districts, 416 sectors, and then further into cells. Every cell is divided into one or more Nyumbakumis, an entity of ten houses. After receiving permission from the national authorities to conduct the survey, we sent letters to the district, sector, and finally the cell level for permission to conduct the survey in each location. The survey was conducted in four provinces: East, South, West, and Kigali. The provinces were selected to include regional variation as well as both urban and rural settings.

As Rwanda has an exceptionally well organized administration, it was possible to obtain lists of the population at each cell level, which enabled a multistage cluster sampling of participants. The team leaders assembled the sampling lists of interviewees in each of the four provinces during the week prior to data collection. Subsequently, for each day of data collection in the field, the team leader prepared the particular interviewee selection in his cell on the day preceding the arrival of the research team.

The multistage sampling procedure was conducted in the following way: As mentioned, each house within a cell belongs to a Nyumbakumi, and a cell consists of one or more Nyumbakumis. In each cell, the heads of household in the Nyumbakumis were consulted, and the two categories of "survivor" and "inyangamugayo" (judge in the gacaca) were identified through the help of representatives from the survivor and inyangamugayo communities. From these lists, names were drawn; for example, in a list with sixty households, every fourth name was chosen. The interviewers chose neighbors by identifying the third house to the right of the survivor or inyangamugayo interviewee, and the head of household was interviewed. The survey included 1,200 people, 300 per province, with an 
equal representation of each subgroup: approximately 100 survivors, 100 inyangamugayo, and 100 neighbors. The three subgroups were selected in order to study how people with different backgrounds experience the truth-telling process and to enable an assessment of psychological health among the people directly involved in this process.

At the beginning of the interview, a statement of confidentiality was read, ensuring that interviews would be kept anonymous and that no identifying information would be retained. At the end of the interview, interviewees were informed that they were welcome to contact the IRC if they needed help or had any questions. No incentive was provided to survey participants.

\section{Questionnaire development and instruments}

The questionnaire consisted of 112 questions divided into ten sections that included background questions, questions regarding exposure to traumatic events during the genocide, scales measuring current symptoms of depression (the Hopkins Symptom Checklist [HSCL]) and posttraumatic stress (the PTSD Checklist-Civilian Version [PCL-C]), and questions concerning attitudes toward trust, coexistence, and the gacaca. ${ }^{7}$

\section{Results}

Table 1 shows that of the total 1,200 survey participants, 51 percent were women. Approximately one-third of the interviewees were survivors $(n=374,31 \%)$, one-third were inyangamugayo (gacaca judges, $n=358$, $30 \%)$, and one-third were neighbors $(n=468,39 \%)$. However, as can be seen in table 1 , inyangamugayo and neighbors have been merged to one respondent group as significant differences between these two subgroups were rare and of little relevance for the analyses here. ${ }^{8}$

Women had been widowed to a significantly larger extent than men among survivors, inyangamugayo/neighbors, and the total population

\footnotetext{
7 The PCL-C and the HSCL are both well-known measures that are widely used, have good psychometric properties, are easily administered by laypeople, and use simple language, which eases translation (Weathers et al. 1993; Blanchard et al. 1996; Veijola et al. 2003). For the PCL-C, see http://www.mirecc.va.gov/docs/visn6/3_PTSD_CheckList_and_Scoring .pdf; for the HSCL, see http://hprt-cambridge.org/screening/hopkins-symptom-checklist.

${ }^{8}$ Please note that the participants of this study were chosen according to specific criteria (survivor, inyangamugayo, neighbor). Therefore, the results of this study should be seen as casting light on attitudes within these three groups and should not be generalized to the whole population of Rwanda.
} 


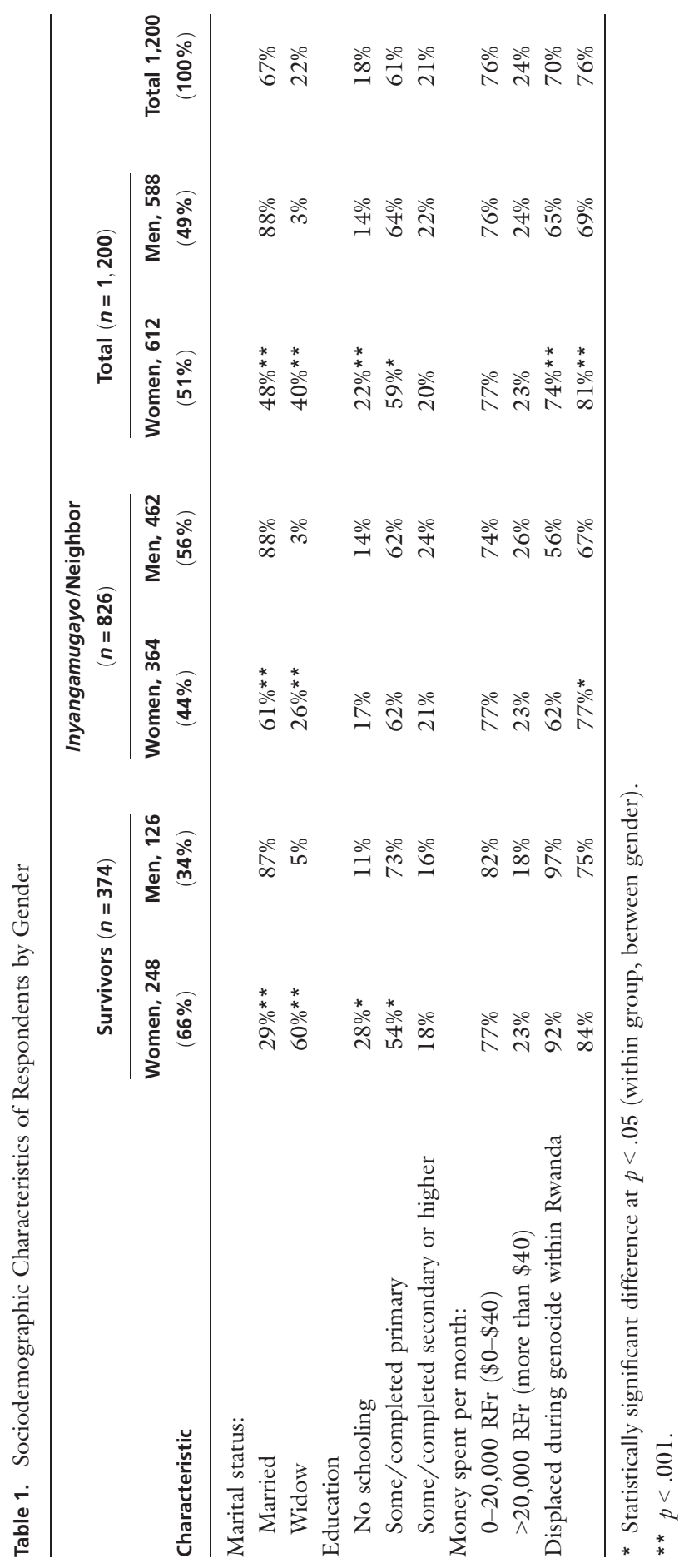


$(p<.001) .{ }^{9}$ Significantly more men were married $(p<.001)$. The level of education was low: around 80 percent of the interviewees, both women and men, had at most primary schooling. The poverty level was high: more than 75 percent spend less than $\$ 40$ per month. ${ }^{10}$ Almost all respondents were in Rwanda during the genocide (94\%). The majority were displaced during that time-over 90 percent of survivors and more than 55 percent of inyangamugayo/neighbors. Significantly more women than men were displaced during the genocide $(74 \%)$, and more women than men were internally displaced within Rwanda $(81 \% ; p<.001)$.

To avoid identifying information, age was taken in categories. Most respondents were in the age-group 35-44 (31\%), followed by ages 25-34 and 45-54 (approximately 25\% each), 55-64 (11\%), 65 and greater (7\%), and 18-24 (4\%). A large majority were farmers (86\%), 5 percent were civil servants, and the remaining vocations included shopkeepers, constructors, and artisans.

The seven different traumatic events listed on the scale can be seen in table 2. Traumatic event exposure was significantly different between women and men, with women having experienced all trauma exposure events to a greater extent than men (for the event "serious illness" the difference is significant at $p<.06$ ). Above all, despite high levels in both sexes, women experienced - to a significantly higher degree than menbeing forced to flee and having a close family member killed; women were also subjected to more sexual violence. One quarter of women survivors reported having been subjected to sexual violence during the genocide, as did 3 percent of women inyangamugayo/neighbors. Of the seventy women who reported sexual violence, sixty were survivors, two were inyangamugayo, and eight were neighbors. One male survivor responded that he had been subjected to sexual violence during the genocide.

Hypothesis 1 stated that women would demonstrate higher levels of war-related trauma events than men. As can be seen in table 3, this hypothesis was confirmed in the results. Table 3 displays the average levels of trauma exposure and exposure to five traumatic events or more during the genocide, as well as PTSD and depression for the survey population. Women were exposed to more traumatic events than men, both in total

9 One-way ANOVAs were used to compare group means. Cross-tabulations were analyzed using chi-squared tests. To describe the association between variables, logistic regression analysis was conducted. Tests were performed using SPSS (Statistical Package for the Social Sciences).

${ }^{10}$ The livelihood of most people in Rwanda is based on subsistence agriculture; therefore, it is more appropriate to make monetary estimations on the basis of how much money one spends per month than on how much one earns. 
Table 2. Trauma Exposure during the Genocide

\begin{tabular}{|c|c|c|c|c|c|c|c|}
\hline \multirow[b]{2}{*}{ Traumatic Events } & \multicolumn{2}{|c|}{$\begin{array}{l}\text { Survivors } \\
(n=374)\end{array}$} & $\begin{array}{r}\text { Inyangaı } \\
\text { Neig } \\
(n=\end{array}$ & $\begin{array}{l}\text { Igayo/ } \\
\text { or } \\
6)\end{array}$ & $\begin{array}{r}\text { Tot } \\
(n=1\end{array}$ & al & \multirow[b]{2}{*}{$\begin{array}{l}\text { Total } \\
(1,200)\end{array}$} \\
\hline & $\begin{array}{c}\text { Women } \\
(248)\end{array}$ & $\begin{array}{l}\text { Men } \\
(126)\end{array}$ & $\begin{array}{c}\text { Women } \\
(364)\end{array}$ & $\begin{array}{l}\text { Men } \\
(462)\end{array}$ & $\begin{array}{c}\text { Women } \\
(612)\end{array}$ & $\begin{array}{l}\text { Men } \\
(\mathbf{5 8 8})\end{array}$ & \\
\hline $\begin{array}{l}\text { Property destroyed or } \\
\text { lost }\end{array}$ & $94 \%$ & $98 \%$ & $57 \%$ & $57 \%$ & $72 \%$ * & $66 \%$ & $69 \%$ \\
\hline Forced to flee & $94 \%$ & $97 \%$ & $65 \%$ & $58 \%$ & $77 \%$ * * & $66 \%$ & $71 \%$ \\
\hline Serious illness & $47 \%$ & $37 \%$ & $22 \%$ & $24 \%$ & $32 \%$ & $27 \%$ & $29 \%$ \\
\hline $\begin{array}{l}\text { Close family member } \\
\text { killed }\end{array}$ & $100 \%$ & $100 \%$ & $80 \% *$ & $74 \%$ & $88 \%$ ** & $80 \%$ & $84 \%$ \\
\hline $\begin{array}{l}\text { Close family member } \\
\text { died from illness }\end{array}$ & $21 \%$ & $23 \%$ & $31 \%$ & $35 \%$ & $27 \% *$ & $32 \%$ & $30 \%$ \\
\hline Sexual violence & $24 \%$ ** & $1 \%$ & $3 \%$ & $0 \%$ & $11 \% * *$ & $0.2 \%$ & $6 \%$ \\
\hline Physical injury & $31 \%$ & $30 \%$ & $6 \%$ & $7 \%$ & $16 \%$ * & $12 \%$ & $14 \%$ \\
\hline
\end{tabular}

* Statistically significant difference at $p<.05$ (within group, between gender).

** $p<.001$.

Table 3. Trauma Exposure Mean, Trauma Exposure of 5 or More Events, PTSD, and Depression

\begin{tabular}{|c|c|c|c|c|c|c|c|}
\hline & \multicolumn{6}{|c|}{ Inyangamugayo/ } & \multirow[b]{3}{*}{$\begin{array}{c}\text { Total } \\
(\mathbf{1}, \mathbf{2 0 0})\end{array}$} \\
\hline & \multicolumn{2}{|c|}{$\begin{array}{l}\text { Survivors } \\
(n=374)\end{array}$} & \multicolumn{2}{|c|}{$\begin{array}{l}\text { Neighbor } \\
(n=826)\end{array}$} & \multicolumn{2}{|c|}{$\begin{array}{c}\text { Total } \\
(n=1,200)\end{array}$} & \\
\hline & $\begin{array}{c}\text { Women } \\
(248)\end{array}$ & $\begin{array}{l}\text { Men } \\
(126)\end{array}$ & $\begin{array}{c}\text { Women } \\
(364)\end{array}$ & $\begin{array}{l}\text { Men } \\
(462)\end{array}$ & $\begin{array}{l}\text { Women } \\
(612)\end{array}$ & $\begin{array}{l}\text { Men } \\
(588)\end{array}$ & \\
\hline $\begin{array}{l}\text { Mean number of trauma } \\
\text { events }\end{array}$ & $4.11 *$ & 3.86 & 2.63 & 2.55 & 3.23 ** & 2.83 & 3.00 \\
\hline 5 or more trauma events & $34 \% *$ & $23 \%$ & $10 \%$ & $8 \%$ & $20 \%$ ** & $11 \%$ & $16 \%$ \\
\hline PTSD & $61 \% * *$ & $31 \%$ & $21 \% * *$ & $11 \%$ & $37 \%$ * * & $16 \%$ & $27 \%$ \\
\hline Depression & $65 \% *$ & $51 \%$ & $35 \% * *$ & $21 \%$ & $47 \%$ * & $28 \%$ & $38 \%$ \\
\hline
\end{tabular}

* Statistically significant difference at $p<.05$ (within group, between gender).

** $p<.001$.

$(p<.001)$ and among survivors $(p<.05)$. More than one-third of women survivors $(34 \%)$ were subjected to five or more traumatic events during the genocide, significantly more so than men $(p<.05)$.

In accordance with hypothesis 2 , women met the criteria for both depression and PTSD to a significantly higher extent than men, in total and within all three subgroups $(p<.001)$. Looking first at the subgroups, for male survivors, over 50 percent met the criteria for depression and nearly 
one-third met the requirements for PTSD. Among women survivors, the situation is even worse: 65 percent met the criteria for depression and 61 percent for PTSD $(p<.001)$. Among male inyangamugayo/neighbors the prevalence of PTSD is 11 percent, significantly lower than among women inyangamugayo/neighbors, where 21 percent meet the requirements for PTSD $(p<.001)$. Concerning depression, the prevalence is 35 percent among women inyangamugayo/neighbors, again higher than the 21 percent among men $(p<.001)$. In sum, the prevalence of depression in total is 47 percent among women and 28 percent among men, while 37 percent of women meet the criteria for PTSD compared to 16 percent of men $(p<.001) .{ }^{11}$

Hypothesis 3 stated that women would demonstrate more negative attitudes toward trust, coexistence, and the gacaca process than men. As is shown in the following, the results of the study confirmed this hypothesis on all three measures. The study employed logistic regression analysis in order to determine the effect of a range of important independent variables, and the particular effect of gender, on attitudes concerning trust, coexistence, and the gacaca. The independent variables included in the analysis were chosen on the basis of theory and earlier research and were tested and retested to determine their influence on the model. ${ }^{12}$ In addition to PTSD and depression, the following background independent variables were included in the initial phases of the analyses: sex, respondent subgroup (survivor or inyangamugayo/neighbor), marital status, age, education level, poverty level, region, pilot community, and level of trauma exposure. However, in the tables, only the variables of interest (i.e., the variables that have a significant association with the attitude under study) are included.

As mentioned earlier, there is high comorbidity $(.539, p<.001)$ between PTSD and depression - that is, PTSD and depression are often associated. ${ }^{13}$ Due to this correlation, problems of multicollinearity arise if both are included in the regression model at once. That is, as the two predictor variables are highly correlated, they explain too much of the same information about the dependent variable (in this case an attitude), and the effect of one is hidden by the other. If the relatively stronger, significant variable (PTSD or depression) is excluded, then the variable with the

${ }^{11}$ The impact of sex, controlling for type and level of trauma exposure, was also tested in multivariate analysis. Hypothesis 2 holds strongly.

${ }^{12}$ See Breslau et al. (1998), Mollica et al. (1998), Brewin, Andrews, and Valentine (2000), Green et al. (2000), Herman (2003), and Pham, Weinstein, and Longman (2004).

${ }^{13}$ In the present study, 81 percent of those with PTSD also have depression. Of the interviewees with depression, 57 percent also have PTSD. 
weaker effect of the two now becomes strongly significant. Therefore, for consistency, in the following tables only the stronger of the two measures of psychological ill health is demonstrated for each attitude.

Meeting the criteria for depression or PTSD strongly predicted a person's tendency to trust. As illustrated in table 4, after controlling for other significant variables, respondents who met the criteria for depression were less likely to believe that most people can be trusted (odds ratio [OR], 0.50; $95 \%$ confidence interval $[\mathrm{CI}], 0.33-0.76)$, were less likely to believe that others will try to be fair (OR, 0.68; 95\% CI, 0.52-0.88), and were more likely to agree that one should be on guard toward other people, even if they are neighbors or friends (OR, 2.76; 95\% CI, 1.84-4.15). Survivors demonstrated significantly lower levels of trust than inyangamugayo/neighbors, and women displayed significantly lower levels of trust than men concerning the two first statements. For the third statement, "one needs to be on guard toward others, even if they are family or friends," depression overruled the influence of being a survivor, which in itself had a significant influence on this attitude, but there was no effect of sex; that is, there was no difference between women and men. For all three statements on trust, no other control variables - such as poverty level or education-were relevant.

As table 5 illustrates, after controlling for other significant variables, meeting the criteria for PTSD was associated with more negative attitudes toward integrating released prisoners (OR, 0.53; 95\% CI, 0.35-0.81),

Table 4. Variables Associated with Attitudes toward Trust*

\begin{tabular}{|c|c|c|c|c|c|c|}
\hline & \multicolumn{2}{|c|}{$\begin{array}{c}\text { Most People Can } \\
\text { Be Trusted }\end{array}$} & \multicolumn{2}{|c|}{ Try to Be Fair } & \multicolumn{2}{|c|}{$\begin{array}{c}\text { On Guard } \\
\text { toward Others }\end{array}$} \\
\hline & $\begin{array}{l}\text { Adjusted OR } \\
\qquad(95 \% \mathrm{Cl})\end{array}$ & $P$-value & $\begin{array}{l}\text { Adjusted OR } \\
\qquad(95 \% \mathrm{Cl})\end{array}$ & $P$-value & $\begin{array}{l}\text { Adjusted OR } \\
\qquad(95 \% \mathrm{Cl})\end{array}$ & $P$-value \\
\hline PTSD & NA & NA & NA & NA & NA & NA \\
\hline Depression & $\begin{array}{c}0.50 \\
(0.33-0.76)\end{array}$ & $<.001$ & $\begin{array}{c}0.68 \\
(0.52-0.88)\end{array}$ & $<.003$ & $\begin{array}{c}2.76 \\
(1.84-4.15)\end{array}$ & $<.001$ \\
\hline Survivor & $\begin{array}{c}0.57 \\
(0.36-0.90)\end{array}$ & $<.02$ & $\begin{array}{c}0.31 \\
(0.23-0.40)\end{array}$ & $<.001$ & NA & NA \\
\hline Sex & NA & NA & $\begin{array}{c}1.51 \\
(1.18-1.93)\end{array}$ & $<.001$ & NA & NA \\
\hline
\end{tabular}

Abbreviations: CI, confidence interval; NA, not applicable because variable was not retained in the final model; OR, odds ratio; PTSD, posttraumatic stress disorder; $P$-value, significance.

* Adjusted ORs were calculated from multivariate regression models adjusting for other significant variables in the model. 
Table 5. Variables Associated with Attitudes toward Coexistence*

\begin{tabular}{|c|c|c|c|c|c|c|}
\hline & \multicolumn{2}{|c|}{ Integrate Prisoners } & \multicolumn{2}{|c|}{$\begin{array}{l}\text { Difficult to Interact } \\
\text { with Accused }\end{array}$} & \multicolumn{2}{|c|}{$\begin{array}{l}\text { Accused Think as } \\
\text { in Genocide }\end{array}$} \\
\hline & $\begin{array}{l}\text { Adjusted OR } \\
\qquad(95 \% \mathrm{Cl})\end{array}$ & $P$-value & $\begin{array}{l}\text { Adjusted OR } \\
\qquad(95 \% \mathrm{Cl})\end{array}$ & $P$-value & $\begin{array}{l}\text { Adjusted OR } \\
\qquad(95 \% \mathrm{Cl})\end{array}$ & $P$-value \\
\hline PTSD & $\begin{array}{c}0.53 \\
(0.35-0.81)\end{array}$ & $<.003$ & $\begin{array}{c}1.67 \\
(1.25-2.24)\end{array}$ & $<.001$ & $\begin{array}{c}2.12 \\
(1.64-2.92)\end{array}$ & $<.001$ \\
\hline Depression & NA & NA & NA & NA & NA & NA \\
\hline Survivor & $\begin{array}{c}0.54 \\
(0.36-0.81)\end{array}$ & $<.003$ & $\begin{array}{c}1.94 \\
(1.48-2.54)\end{array}$ & $<.001$ & $\begin{array}{c}3.10 \\
(2.36-4.08)\end{array}$ & $<.001$ \\
\hline Sex & $\begin{array}{c}1.87 \\
(1.23-2.82)\end{array}$ & $<.003$ & $\begin{array}{c}0.72 \\
(0.57-0.92)\end{array}$ & $<.008$ & NA & NA \\
\hline
\end{tabular}

Abbreviations: CI, confidence interval; NA, not applicable because variable was not retained in the final model; OR, odds ratio; PTSD, posttraumatic stress disorder; $P$-value, significance. * Adjusted ORs were calculated from multivariate regression models adjusting for other significant variables in the model.

with interviewees being more likely to feel that it is difficult to interact with someone who has been accused in the gacaca (OR, 1.67; 95\% CI, 1.252.24) and more likely to believe that the accused still think as they did during the genocide $(\mathrm{OR}, 2.12 ; 95 \% \mathrm{CI}, 1.64-2.92)$ than those who did not meet the PTSD symptom criteria. Survivors demonstrate the same attitude pattern as respondents with PTSD. There is a clear gender effect in the attitudes toward coexistence: men have more positive attitudes toward integrating prisoners than women (OR, 1.87; 95\% CI, 1.23-2.82), and women find it more difficult than men to interact with someone who has been accused in the gacaca (OR, 0.72; 95\% CI, 0.57-0.92).

Table 6 demonstrates variables associated with attitudes toward the truth and reconciliation process in Rwanda, the gacaca process. After controlling for other significant variables, meeting the criteria for PTSD is negatively associated with believing that it is easier to coexist after the gacaca (OR, 0.72; 95\% CI, 0.51-0.98). That is, respondents with clinically significant symptoms of PTSD do not believe the gacaca makes living together easier, and neither do survivors (compared to inyangamugayo/ neighbors; OR, 0.36; 95\% CI, 0.26-0.50) or women (compared to men; OR, 2.10; 95\% CI, 1.53-2.89). Further, respondents who meet the depression criteria are more likely to believe that the gacaca intensifies suffering (OR, 1.60; 95\% CI, 1.22-2.08) and that it opens wounds (OR, 2.01; $95 \%$ CI, 1.54-2.63) than those who are not depressed. Depression is also strongly associated with the opinion that after the gacaca, there is often 


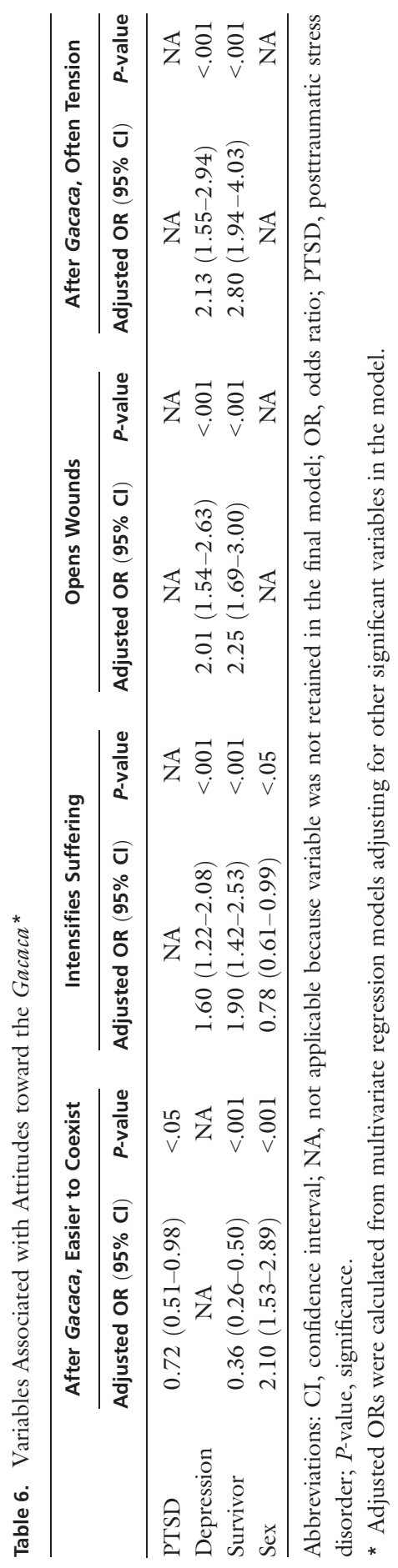

This content downloaded from 130.238.171.093 on January 27, 2016 02:00:02 AM 
tension between neighbors (OR, 2.13; 95\% CI, 1.55-2.94). Again, being a survivor follows the same pattern. Finally, women are more likely than men to believe that the gacaca intensifies suffering (OR, 0.78; 95\% CI, $0.61-$ $0.99) .^{14}$

In sum, the multivariate analyses above confirm the existence of an important gender effect in attitudes toward trust, coexistence, and the gacaca. All gender differences hold when controlling for type and level of traumatic events. In line with hypothesis 3, women in general demonstrate more negative attitudes toward these issues than men. Let us now turn to a discussion of why this may be the case.

\section{Discussion}

A strong gender effect is apparent across all analyses of this study. In line with hypotheses 1 and 2, women demonstrated significantly higher levels of war-related trauma than men and also significantly higher levels of depression and PTSD. This finding is in accordance with previous research (Ventevogel et al. 2007). On the other hand, the finding that women reported more trauma is not. This finding differs from nonwar situations, where men report higher levels of traumatic events than women, as discussed above (Gavrandidou and Rosner 2003; Solomon, Gelkopf, and Bleich 2005). Considering that women are subjected to more nonlethal violence in war (Human Security Centre 2005; Okasha 2007), the findings of this study might be expected, but to my knowledge they have not been articulated or studied previously.

Furthermore, due to the type and levels of trauma women are subjected to in war, hypothesis 3 proposed that women in the peacebuilding phase would demonstrate lower levels of trust and more negative attitudes toward coexistence and the gacaca process than men. Hypothesis 3 was confirmed in the results. Concerning trust, women displayed significantly lower levels than men on two of three trust measures. Significantly, women were less likely than men to believe that most people can be trusted or that others will try to be fair. Few studies exist of the relation between gender and trust, and those that do exist offer no clear results; hence, future research is needed for further comparisons. ${ }^{15}$ Concerning coexistence, again

\footnotetext{
${ }^{14}$ Analyses at the subgroup level reveal that women survivors strongly agree that "After gacaca, often tension." In a larger study, further gender differences may have been detected.

15 The few existing studies include a working paper from Afrobarometer, which found no significant gender differences on interpersonal trust in Nigeria and Ghana (Kuenzi 2008); in Ghana, boys demonstrated higher distrust than girls (Mansaray 2008); in the United States,
} 
on two measures of three, women demonstrated significantly more negative attitudes than men: men were more positive at the prospect of integrating prisoners than women, and women found it more difficult to interact with someone who had been accused in the gacaca than men. Finally, concerning the gacaca, women were significantly more negative than men on two of four measures: women did not believe the gacaca makes living together easier, but they did believe, to a higher extent than men, that the gacaca intensifies suffering. Importantly, in none of the measures on trust, coexistence, or the gacaca did men demonstrate more negative attitudes than women.

Considering that women had experienced higher levels of all types of trauma than men, their reluctance regarding integration, coexistence, and the gacaca might be expected. The difficulty of meeting one's perpetrator in the street or living as his neighbor should not be underestimated. Hence, the propositions put forward in this article seem to hold: the attitudinal gender differences may well depend on the type and level of traumatic exposure during the war.

However, alternative explanations for the results found here should be considered. For example, socioeconomic changes may have differed for women and men during and after the genocide, with a subsequent effect on attitudes. Indeed, the safety of the family network was shattered for many women. In the data presented here, significantly more women than men had a close family member killed during the genocide, and 40 percent of women, versus 3 percent of men, were widowed. As mentioned, social support has been found to have an important protective effect against PTSD, particularly among women (Ahern et al. 2004); loss of loved ones is likely to be an aggravating factor for women's psychological ill health. Loss of family also means that women-both survivors and others-are to a large extent the sole providers for the family in postgenocide Rwanda. In an agrarian society where survival depends on the crops from one's own land plot, being alone creates a particular challenge and vulnerability for women in everyday life. Further analyses of the survey data reveal that many more women than men perceive their poverty level to be high. When counting in figures, however, men and women demonstrate very similar levels of disposable revenue. Women's perception of struggling more financially may be a result of having experienced worse negative income shocks during and after the genocide, an aspect that would be interesting to look at in future research.

women were found to be less trusting but more trustworthy than men (Buchan, Croson, and Solnick 2008). 


\section{Conclusion}

For the first time, the present study applies the women and peace hypothesis to an African peacebuilding setting, finding that after war women had more negative attitudes than men toward trust, coexistence, and the peacebuilding process. The results of this study suggest that women's experiences of armed conflict - the type and level of trauma they are exposed to - are the basis for these more negative attitudes toward issues related to peace, proposing that in peacebuilding settings, the women and peace hypothesis should take the postconflict context, and especially warrelated trauma, into account.

Further cross-country analyses of women and men's experiences of peacebuilding processes are needed to determine to what extent the results found here are generalizable to other postconflict settings. The Rwandan genocide can be seen as unique in its horrific intensity and scope. However, it has been argued that it was not unique in terms of structure. For example, similar to other cases, the Rwandan government organized and recruited a paramilitary, the Interahamwe, who committed the vast majority of the killings (Strauss 2006). Paramilitaries are a common feature of genocides, and rapid recruitment to the regular and paramilitary forces is an important predictor of genocide onset (Colaresi and Carey 2008). It has been argued that the government needs a paramilitary to carry out the atrocities it orchestrates in order to keep distance and maintain deniability (Alvarez 2006). Hence, while every event of genocide is unique, there are certain structural characteristics that can be seen across events as well. As mentioned above, with the emergence of research pointing to the complexities of reconciliation processes and the promises and pitfalls involved, more studies are needed to identify under which conditions truth and reconciliation processes can best promote peace-not fear or the resumption of violence.

In conclusion, some fundamental areas for future research emerge on the basis of this study. While it was beyond the scope of this study to include questions about coping strategies and perceived social support, these would be important to include in future studies. It would also be important for future research to systematically explore the women and peace hypothesis in a variety of peacebuilding settings. Another aspect worthy of future study would be to examine whether women-despite high experiences of war-related trauma-are better able to suppress negative feelings for the sake of peace than men. That is, while more negative in their attitudes, do women still do more for peace? In a more technical sense, the results found here lead to one practical implication for postconflict research: if women report higher levels of psychological ill health 
after war because they are left to survive, this would argue against using higher cutoff scores for women and lower ones for men when assessing psychological ill-health, which has been done in previous research (Ventevogel et al. 2007). Differences would not be due to cultural, gendered differences in over- or underreporting but due to differences in types and level of actual experience. Finally, future studies would benefit from investigating whether women's more negative attitudes may also be a result of experiences during the postconflict transitional justice process itself. If women experience the peacebuilding process as more challenging, this may affect their attitudes.

With regard to policy implications, the results found here suggest that it is critical to ensure women's security in the postconflict peacebuilding period, both physically and emotionally. The challenges women face in the aftermath of war must be taken into account when designing peacebuilding processes in order to assure that they actually advance peace and do no harm-for women and for men.

Department of Peace and Conflict Research

Uppsala University

\section{References}

Ackerly, Brooke A., Maria Stern, and Jacqui True, eds. 2006. Feminist Methodologies for International Relations. Cambridge: Cambridge University Press.

Ackerly, Brooke A., and Jacqui True. 2010. Doing Feminist Research in Political and Social Science. Basingstoke: Palgrave Macmillan.

Ahern, Jennifer, Sandro Galea, William G. Fernandez, Bajram Koci, Ronald Waldman, and David Vlahov. 2004. "Gender, Social Support, and Posttraumatic Stress in Postwar Kosovo." Journal of Nervous and Mental Disease 192 (11):762-70.

Alvarez, Alex. 2006. "Militias and Genocide." War Crimes, Genocide, and Crimes against Humanity, no. 2: 1-33.

Arcel, Libby Tata, and Marianne Kastrup. 2004. "War, Women and Health." Nordic Journal of Women's Studies 12(1):40-47.

Bayer, Christophe Pierre, Fionna Klasen, and Hubertus Adam. 2007. "Association of Trauma and PTSD Symptoms with Openness to Reconciliation and Feelings of Revenge among Former Ugandan and Congolese Child Soldiers." JAMA 298(5):555-59.

Blanchard, Edward B., Jacqueline Jones-Alexander, Todd C. Buckley, and Catherine A. Forneris. 1996. "Psychometric Properties of the PTSD Checklist (PCL)." Behavior Research and Therapy 34(8):669-73.

Bolocan, Maya Goldstein. 2004. "Rwandan Gacaca: An Experiment in Transitional Justice." Journal of Dispute Resolution 2004(2):355-400. 
Bolton, Paul, and Lincoln Ndogoni. 2000. "Cross-Cultural Assessment of TraumaRelated Mental Illness.” Research report, USAID and Tulane University. http:// www.certi.org/publications/Manuals/cross-cultural-10.PDF.

Breslau, Naomi, Ronald C. Kessler, Howard D. Chilcoat, Lonni R. Schultz, Glenn C. Davis, and Patricia Andreski. 1998. "Trauma and Posttraumatic Stress Disorder in the Community: The 1996 Detroit Area Survey of Trauma." Archives of General Psychiatry 55(7):626-32.

Brewin, Chris R., Bernice Andrews, and John D. Valentine. 2000. "Meta-Analysis of Risk Factors for Posttraumatic Stress Disorder in Trauma-Exposed Adults." Journal of Consulting and Clinical Psychology 68(5):748-66.

Brounéus, Karen. 2008. "Truth Telling as Talking Cure? Insecurity and Retraumatization in the Rwandan Gacaca Courts." Security Dialogue 39(1):55-76.

- 2010. "The Trauma of Truth Telling: Effects of Witnessing in the Rwandan Gacaca Courts on Psychological Health." Journal of Conflict Resolution 54 (3):408-37.

. 2011. "In-Depth Interviewing: The Process, Skill and Ethics of Interviews in Peace Research." In Understanding Peace Research: Methods and Challenges, ed. Kristine Höglund and Magnus Öberg, 130-45. London: Routledge.

Buchan, Nancy R., Rachel T. A. Croson, and Sara Solnick. 2008. "Trust and Gender: An Examination of Behavior and Beliefs in the Investment Game." Journal of Economic Behavior and Organization 68(3-4):466-76.

Caprioli, Mary. 2000. “Gendered Conflict.” Journal of Peace Research 37(1):51-68.

- 2005. "Primed for Violence: The Role of Gender Inequality in Predicting Internal War." International Studies Quarterly, no. 49: 161-78.

Caprioli, Mary, and Mark A. Boyer. 2001. "Gender, Violence, and International Crisis." Journal of Conflict Resolution 45(4):503-18.

Clark, Phil. 2007. "Hybridity, Holism, and Traditional Justice: The Case of the Gacaca Courts in Post-genocide Rwanda." George Washington International Law Review 39(4):765-837.

Cockburn, Cynthia. 2001. "The Gendered Dynamics of Armed Conflict and Political Violence." In Victims, Perpetrators or Actors? Gender, Armed Conflict and Political Violence, ed. Caroline O. N. Moser and Fiona C. Clark, 13-29. New York: Zed.

Colaresi, Michael, and Sabine C. Carey. 2008. "To Kill or to Protect: Security Forces, Domestic Institutions, and Genocide." Journal of Conflict Resolution 52(1):39-67.

Confortini, Catia Cecilia. 2012. Intelligent Compassion: Feminist Critical Methodologv in the Women's International League for Peace and Freedom. Oxford: Oxford University Press.

Conover, Pamela Johnston, and Virginia Sapiro. 1993. "Gender, Feminist Consciousness, and War." American Journal of Political Science 37(4):1079-99.

Eichenberg, Richard C. 2003. "Gender Differences in Public Attitudes toward the Use of Force by the United States, 1990-2003." International Security 28 (1):110-41. 
Elshtain, Jean Bethke. 1987. Women and War. Sussex: Harvester.

Ember, Carol R., and Melvin Ember. 1997. "Violence in the Ethnographic Record: Results of Cross-Cultural Research on War and Aggression." In Troubled Times: Violence and Warfare in the Past, ed. Debra L. Martin and David W. Frayer, 1-20. Amsterdam: Gordon and Breach.

Erchak, Gerald M., and Richard Rosenfeld. 1994. "Societal Isolation, Violent Norms, and Gender Relations: A Reexamination and Extension of Levinson's Model of Wife Beating." Cross-Cultural Research 28(2):111-33.

Ford, Nathan, Edward J. Mills, Rony Zachariah, and Ross Upshur. 2009. "Ethics of Conducting Research in Conflict Settings." Conflict and Health 3(7). http://www.ncbi.nlm.nih.gov/pmc/articles/PMC2717053/pdf/1752-1505 -3-7.pdf.

Gavrandidou, Maria, and Rita Rosner. 2003. "The Weaker Sex? Gender and Posttraumatic Stress Disorder." Depression and Anxiety 17(3):130-39.

Green, Bonnie L., Lisa A. Goodman, Janice L. Krupnick, Carole B. Corcoran, Rachel M. Petty, Patricia Stockton, and Nicole M. Stern. 2000. "Outcomes of Single versus Multiple Trauma Exposure in a Screening Sample." Journal of Traumatic Stress 13(2):271-86.

Harbom, Lotta, and Peter Wallensteen. 2010. "Armed Conflicts, 1946-2009." Journal of Peace Research 47(4):501-9.

Haskell, Sally G., Kirsha S. Gordon, Kristin Mattocks, Mona Duggal, Joseph Erdos, Amy Justice, and Cynthia A. Brandt. 2010. "Gender Differences in Rates of Depression, PTSD, Pain, Obesity, and Military Sexual Trauma among Connecticut War Veterans of Iraq and Afghanistan." Journal of Women's Health 19(2):267-71.

Herman, Judith Lewis. 1997. Trauma and Recovery. Rev. ed. New York: Basic.

- 2003. "The Mental Health of Crime Victims: Impact of Legal Intervention." Journal of Traumatic Stress 16(2):159-66.

Hudson, Valerie M., Mary Caprioli, Bonnie Ballif-Spanvill, Rose McDermott, and Chad F. Emmett. 2008/9. "The Heart of the Matter: The Security of Women and the Security of States." International Security 33(3):7-45.

Human Rights Watch. 2004. "Struggling to Survive: Barriers to Justice for Rape Victims in Rwanda." Report, Human Rights Watch, New York. http://www .hrw.org/reports/2004/09/30/struggling-survive.

- 2011. "Justice Compromised: The Legacy of Rwanda's CommunityBased Gacaca Courts.” Report, Human Rights Watch, New York. http://www .hrw.org/sites/default/files/reports/rwanda051 lwebwcover_0.pdf.

Human Security Centre. 2005. "Human Security Report 2005: War and Peace in the 2lst Century." Report, Human Security Centre, University of British Columbia. http://www.hsrgroup.org/human-security-reports/2005/text .aspx.

Hunt, Kate, and Ellen Annandale. 1999. "Relocating Gender and Morbidity: Examining Men's and Women's Health in Contemporary Western Societies." Social Science and Medicine 48(1):1-5. 
Ingelaere, Bert. 2008. "The Gacaca Courts in Rwanda.” In "Traditional Justice and Reconciliation after Violent Conflict: Learning from African Experiences," ed. Luc Huyse and Marc Salter, 25-59. Report, International IDEA, Stockholm. http://www.idea.int/publications/traditional_justice/upload/Chapter _2_The_Gacaca_Courts_in_Rwanda.pdf.

Jones, Adam. 2000. "Gendercide and Genocide." Journal of Genocide Research 2 (2):185-211.

Kuenzi, Michelle T. 2008. "Social Capital and Political Trust in West Africa." Working paper no. 96, Afrobarometer, Cape Town. http://www.mercury.ethz .ch/serviceengine/Files/ISN/91878/ipublicationdocument_singledocument /e489c6f8-b438-4122-a0e2-4lcdb7d80b2b/en/AfropaperNo96.pdf.

Macintyre, Sally, Graeme Ford, and Kate Hunt. 1999. “Do Women 'Over-report' Morbidity? Men's and Women's Responses to Structured Prompting on a Standard Question on Long Standing Illness.” Social Science and Medicine 48 (1):89-98.

MacKinnon, Catharine. 2005. "Genocide's Sexuality." In Political Exclusion and Domination, ed. Melissa S. Williams and Stephen Macedo, 313-56. New York: New York University Press.

Mansaray, Abu Sidikie. 2008. "Gender, Social Trust and Political Socialization in Ghanaian Education: Implications for Shaping Political Beings in the Wa $\mathrm{Mu}$ nicipality." Studies in Gender and Development in Africa, no. 2: 95-111.

Maoz, Ifat. 2009. "The Women and Peace Hypothesis? The Effect of Opponent Negotiators' Gender on the Evaluation of Compromise Solutions in the Israeli-Palestinian Conflict." International Negotiation 14(3):519-36.

McKay, Susan. 2000. "Gender Justice and Reconciliation." Women's Studies International Forum 23(5):561-70.

Melander, Erik. 2005a. "Gender Equality and Intrastate Armed Conflict." International Studies Quarterly 49(4):695-714.

_. 2005b. "Political Gender Equality and State Human Rights Abuse." Journal of Peace Research 42(2):149-66.

Melvern, Linda. 2000. A People Betrayed: The Role of the West in Rwanda's Genocide. London: Zed.

Modvig, J., J. Pagaduan-Lopez, J. Rodenburg, C. M. D. Salud, R. V. Cabigon, and C. I. A. Panelo. 2000. "Torture and Trauma in Post-conflict East Timor." Lancet 356(9243):1763.

Mollica, Richard F., Barbara Lopes Cardozo, Howard J. Osofsky, Beverley Raphael, Alastair Ager, and Peter Salama. 2004. "Mental Health in Complex Emergencies." Lancet 364(9450):2058-67.

Mollica, Richard F., Karen Donelan, Svang Tor, James Lavelle, Christopher Elias, Martin Frankel, and Robert J. Blendon. 1993. "The Effect of Trauma and Confinement on Functional Health and Mental Health Status of Cambodians Living in Thailand-Cambodia Border Camps." JAMA 270(5):581-86.

Mollica, Richard F., Keith McInnes, Charles Poole, and Svang Tor. 1998. “DoseEffect Relationships of Trauma to Symptoms of Depression and Posttraumatic 
Stress Disorder among Cambodian Survivors of Mass Violence." British Journal of Psychiatry, no. 173: 482-88.

Okasha, Ahmed. 2007. "Mental Health and Violence: WPA Cairo DeclarationInternational Perspectives for Intervention." International Review of Psychiatry 19(3):193-200.

Pham, Phuong N., Harvey M. Weinstein, and Timothy Longman. 2004. "Trauma and PTSD Symptoms in Rwanda: Implications for Attitudes toward Justice and Reconciliation." JAMA 292(5):602-12.

Prunier, Gérard. 1995. The Rwanda Crisis: History of a Genocide. London: Hurst.

Ruddick, Sara. 1998. "Woman of Peace': A Feminist Construction.” In The Women and War Reader, ed. Lois Ann Lorentzen and Jennifer Turpin, 213-26. New York: New York University Press.

Sarkin, Jeremy. 2001. "The Tension between Justice and Reconciliation in Rwanda: Politics, Human Rights, Due Process and the Role of the Gacaca Courts in Dealing with the Genocide." Journal of African Law 45(2):143-72.

Solomon, Zahava, Marc Gelkopf, and Avraham Bleich. 2005. "Is Terror GenderBlind? Gender Differences in Reaction to Terror Events." Social Psychiatry and Psychiatric Epidemiology 40(12):947-54.

Srinivasa Murthy, R. 2007. "Mass Violence and Mental Health-Recent Epidemiological Findings." International Review of Psychiatry 19(3):183-92.

Staub, Ervin, and Laurie Anne Pearlman. 2001. "Healing, Reconciliation, and Forgiving after Genocide and Other Collective Violence." In Forgiveness and Reconciliation: Religion, Public Policy, and Conflict Transformation, ed. Raymond G. Helmick and Rodney L. Petersen, 205-27. Radnor, PA: Templeton Foundation Press.

Stein, Dan J., Soraya Seedat, Debra Kaminer, Hashim Moomal, Allen Herman, John Sonnega, and David R. Williams. 2008. "The Impact of the Truth and Reconciliation Commission on Psychological Distress and Forgiveness in South Africa." Social Psychiatry and Psychiatric Epidemiology 43(6):462-68.

Stein, Murray B., John R. Walker, and David R. Forde. 2000. "Gender Differences in Susceptibility to Posttraumatic Stress Disorder." Behavior Research and Therapy 38(6):619-28.

Straus, Scott. 2006. The Order of Genocide: Race, Power, and War in Rwanda. Ithaca, NY: Cornell University Press.

Sylvester, Christine. 1994. Feminist Theory and International Relations in a Postmodern Era. Cambridge: Cambridge University Press.

Tessler, Mark, Jodi Nachtwey, and Audra Grant. 1999. "Further Tests of the Women and Peace Hypothesis: Evidence from Cross-National Survey Research in the Middle East." International Studies Quarterly 43(3):519-31.

Tessler, Mark, and Ina Warriner. 1997. "Gender, Feminism, and Attitudes toward International Conflict: Exploring Relationships with Survey Data from the Middle East." World Politics 49(2):250-81.

Tickner, J. Ann. 1992. Gender in International Relations: Feminist Perspectives on Achieving Global Security. New York: Columbia University Press. 
Uvin, Peter. 2003. "The Gacaca Tribunals in Rwanda." In "Reconciliation after Violent Conflict: A Handbook," ed. David Bloomfield, Teresa Barnes, and Luc Huyse, 116-21. Report, International IDEA, Stockholm. http://www.un.org /en/peacebuilding/pbso/pdf/Reconciliation-After-Violent-Conflict-A -Handbook-Full-English-PDF.pdf.

Van de Velde, Sarah, Piet Bracke, and Katia Levecque. 2010. "Gender Differences in Depression in 23 European Countries: Cross-National Variation in the Gender Gap in Depression." Social Science and Medicine 71(2):305-13.

Veijola, Juha, Jari Jokelainen, Kristian Läksy, Liisa Kantojärvi, Pirkko Kokkonen, Marjo-Riitta Järvelin, and Matti Joukamaa. 2003. "The Hopkins Symptom Checklist-25 in Screening DSM-III-R Axis-I Disorders." Nordic Journal of Psychiatry 57(2):119-23.

Ventevogel, Peter, Gieljan De Vries, Willem F. Scholte, Nasratullah Rasa Shinwari, Hafizullah Faiz, Ruhullah Nassery, Wim van den Brink, and Miranda Olff. 2007. "Properties of the Hopkins Symptom Checklist-25 (HSCL-25) and the Self-Reporting Questionnaire (SRQ-20) as Screening Instruments Used in Primary Care in Afghanistan." Social Psychiatry and Psychiatric Epidemiology 42 (4):328-55.

Vinck, Patrick, Phuong N. Pham, Eric Stover, and Harvey M. Weinstein. 2007. "Exposure to War Crimes and Implications for Peace Building in Northern Uganda." JAMA 298(5):543-54.

Weathers, Frank W., Brett T. Litz, Debra S. Herman, Jennifer A. Huska, and Terence M. Keane. 1993. "The PTSD Checklist (PCL): Reliability, Validity, and Diagnostic Utility." Paper presented at the annual meeting of the International Society for Traumatic Stress Studies, San Antonio, TX, October.

Weissman, Myrna M., Roger C. Bland, Glorisa J. Canino, et al. 1996. "CrossNational Epidemiology of Major Depression and Bipolar Disorder." JAMA 276(4):293-99.

Wilcox, Clyde, Lara Hewitt, and Dee Allsop. 1996. "The Gender Gap in Attitudes toward the Gulf War: A Cross-National Perspective." Journal of Peace Research 33(1):67-82.

Yablon, Yaacov Boaz. 2009. "Gender Differences in the Consistency of Attitudes towards Peace." Women's Studies International Forum 32(4):305-10. 